\title{
KENDALA-KENDALA PENCEGAHAN PERDAGANGAN PAKAIAN BEKAS IMPOR DI KOTA MALANG
}

\author{
Risma Nur Arifah \\ Fakultas Syariah UIN Maulana Malik Ibrahim Malang \\ mrs_reyzma@yahoo.co.id
}

\begin{abstract}
Abstrak
Malang is one of biggest district in selling imported second-hand clothes with the big community of sellers that spreading in many shopping central. Even with the prohibition from central government and suggestion from the government of Malang district, the number of second-hand clothes buyers keeps getting higher. The focus of this research is in Malang district, collecting data by using interview method to the employee of the Government of Industrial and Commerce Affairs (DISPERINDAG) of Malang district and the sellers of imported second-hand clothes. On the one side, the result of interview shows that sellers have already aware of this prohibition from mass media, but they just unwilling to apply this provision because this is their only way to fulfill their necessities of life. While on the other side the Government of Industrial and Commerce Affairs (DISPERINDAG) of Malang city has obstacles in preventing this to happen; such as the difficulties in realizing the provision of government that allow them only in state of socialization of this preovision, and the difficulties in finding second option to replace their work as a sellers.
\end{abstract}

Kota Malang merupakan salah satu kota dengan penjualan pakaian bekas impor dengan jumlah pedagang yang sangat besar dan tersebar di beberapa pusat perbelanjaan. Betapapun telah terdapat larangan dari Pemerintah Pusat dan himbauan dari Pemerintah Kota Malang, namun perdagangan pakaian impor bekas dengan jumlah pedagang dan konsumennya tetap semakin menjamur. Fokus penelitian dilakukan di Kota Malang, pengumpulan datanya dilakukan dengan metode interview kepada pegawai Dinas Perindustrian dan Perdagangan (DISPERINDAG) Kota Malang dan pedagang pakaian impor bekas. Hasil interview menunjukkan bahwa para pedagang sudah mengetahui adanya larangan tersebut dari berbagai sumber terutama melalui media massa, namun mereka enggan mentaatinya dengan alasan bahwa menjual pakaian bekas impor merupakan mata pencaharian mereka. Disamping itu, Dinas Perindustrian dan Perdagangan (DISPERINDAG) Kota Malang memiliki kendala untuk melakukan pencegahan antara lain; sulitnya melakukan realisasi peraturan pemerintah terhadap kondisi di lapangan sehingga upaya yang dilakukan hanya pada taraf sosialisasi, dan sulitnya mencarikan second opinion terhadap mata pencaharian pedagang.

Kata Kunci: Pencegahah, perdagangan, pakaian bekas, 
Maraknya perdagangan pakaian bekas impor tidak saja membuat heboh Kota Malang, melainkan juga terjadi dibeberapa kotakota besar seperti Cirebon, Yogyakarta, Denpasar, Surabaya dan kota lainnya. Hebohnya perdagangan pakaian bekas impor samasekali tidak menyurutkan para pedagang untuk berdagang, bahkan menambah banyak peminat pakaian bekas impor mengingat harga yang ditawarkan sangat murah dan para pembeli juga tidak perlu berfikir untuk mengetahui asal usul pakaian bekas impor tersebut.1

Penjual pakaian bekas impor di Kota Malang sangat besar dan tersebar tidak hanya tersebar di beberapa pusat perbelanjaan seperti Pasar Comboran, Pasar Kasin, Pasar Besar Malang, Kawasan Mergosono, Kawasan Joyo, namun juga terdapat di beberapa pusat perbelanjaan Modern seperti mall Malang Town Square. Beroperasinya bisnis pakaian impor bekas tersebut dimulai sejak tahun 1960-an dan jumlah konsumennya semakin tinggi dari tahun ke tahun. Distribusi pakaian impor bekas banyak didatangkan dari beberapa negara, seperti Malaysia, Singapura, Jepang dan Korea.

Rachmat Gobel ketika menjabat sebagai MenteriPerdagangan telah melarang perdagangan pakaian impor bekas berdasarkan Permendag Nomor 51/M-DAG/7/2015 dengan alasan berbahaya untuk kesehatan karena pada pakaian bekas ditemukan bakteri dan perdagangan tersebut mematikan industri dalam negeri. Berdasar Point (a) Permendag Nomor 51/MDAG/7/2015 yang berbunyi "pakaian bekas import berpotensimembahayakan kesehatan manusia sehingga tidak aman untuk dimanfaatkan dan digunakan oleh masyarakat", pemerintah melarang para pedagang melanjutkan usaha menjual pakaian bekas impor karena ditemukan bakteri yang berbahaya bagi kesehatan, salah satunya adalah ditemukannya bakteri monogtigones pada

\footnotetext{
${ }^{1}$ Fenomena seperti ini sering kita saksikan dalam media-media cetak maupun elektronik, contohnya adalah kasus tercemarnya susu bayi oleh bakteri Enterobacter Sakazakii dan produk melamin dari negara Cina yang membahayakan karena tidak aman (non food grade) untuk digunakan pada produk makanan. Lihat: Iffaty Nasyiah, Pos Pengaduan Konsumen Sebagai Aplikasi UUPK, (Fakultas Syariah: Penelitian, 2014)
}

pakaian impor bekas. Masalah lain yang sulit diatasi pemerintah guna melarang perdagangan pakaian bekas impor tersebut adalah masuknya barang yang tidak terkontrol karena melaui pelabuhan-pelabuhan kecil di beberapa pulau secara ilegal dan semua kalangan masyarakat mudah menjangkaunya.

Dinas Perindustrian dan Perdagangan Kota Malang sebagai lembaga negara dibawah kordinasi tugas Kementerian Perindustrian dan Perdaganan Republik Indonesia sudah semestinya melaksanakan amanat untuk melaksanakan Permendag Nomor 51/MDAG/7/2015 yaitu mencegah berkembangnya perdagangan pakaian impor bekas di Kota Malang. Namun realitanya, Dinas Perindustrian dan Perdagangan Kota Malang mengalami kesulitan dalam merealisasikan peraturan tersebut karena tidak sedikit para pedagang pakaian impor bekas menganggap kebijakan pemerintah tersebut tidak masuk akal dan cenderung terlalu mengada-ngada. Menurut pedagang $b a b e b o$, sulitnya ketersediaan lapangan kerja serta terjadinya pemutusan hubungan kerja (PHK) yang dilakukan secara besarbesaran oleh sejumlah perusahaan akibat perlambatan ekonomi mengakibatkan munculnya pengangguran dan akan menambah lagi pengangguran jika perdagangan pakaian impor bekas dihentikan. Di sisi lain, bagi konsumen membeli pakaian impor bekas merupakan salah satu upaya meminimalisir pengeluaran dan mereka masih menganggap pakaian impor bekas masih layak digunakan dengan variatif model baju (design).

Dalam tataran teori dan praktiknya, negara memiliki tugas untuk memberikan perlindungan secara maksimal atas warga negaranya, baik untuk urusan pendidikan, kesehatan, terlebih juga pada persoalan sosial ekonomi rakyatnya. Dalam konteks perdagangan pakaian impor bekas tersebut, tanggung jawab negara dan pemerintah terlihat membingungkan layaknya dua sisi mata uang sebab disatu sisi negara berkewajiban melindungi kesehatan rakyatnya atas bahaya yang muncul dari pakaian impor bekas. Namun disisi lainnya, negara dan pemerintah juga dituntut untuk melindungi 
dan mensejahterakan rakyatnya dalam konteks sosial ekonomi.

Terkait dengan persoalan pakaian impor bekas, pemerintah selaku penyelenggara Negara membuat pengaturan yaitu diterbitkannya Undang-Undang Nomor 7 Tahun 2014 Tentang Perdagangan, yang disebutkan secara tegas dalam Pasal 47 dengan menyatakan bahwa "importir wajib mengimpor barang dalam keadaan baru". Selain itu, pemerintah mempertegasnya kembalidengan dikeluarkannya Kepmenperindag RI Nomor 230/MPP/Kep/7/1977 tentang Barang Yang Diatur Tata Niaga Impornya, dan Kepmenperindag RI Nomor 642/MPP/ Kep/9/2002 Tentang Perubahan Lampiran I Kepmenperindag RI Nomor 230/MPP/Kep/7/1977 Tentang Barang Yang Diatur Tata Niaga Impornya, yang didalamnya menyebutkan bahwa "dilarang untuk impor barang gombal baru dan bekas".

Namun terdapat ambiguitas peraturan antara peraturan tersebut diatas ketika dibandingkan dengan Pasal 8 ayat 2 Undang-Undang Nomor 8 Tahun 1999 Tentang Perlindungan Konsumen yang menyebutkan bahwa "pelaku usaha dilarang memperdagangkan barang yang rusak, cacat, bekas dan tercemar tanpa memberkan informasi secara lengkap dan benar atas barang yang dimaksud".2 Ambiguitas peraturan terlihat dari isi Pasal 8 Ayat 2 yang seolah-olah masih diperbolehkannya penjualan pakaian impor bekas.

Sejatinya keberadaan praktek perdagangan pakaian bekas impor sudah ada sejak sebelum keluarnya ketentuan dalam Undang-Undang Perlindungan Konsumen memberikan sinyalemen bahwa memperdagangkan barang rusak, cacat dan bekas diperbolehkan sejauh ada informasi yang jelas sehingga konsumen dapat mengetahui kualitas dan kuantitas barang yang akan dibeli. Disinilah letak pertentangan antar peraturan tersebut sebab disatu sisi masih berlakunya UUPK tidak memiliki kesinambungan dengan Undang-Undang perdagangan, tepatnya antara Pasal 8 UUPK dengan Pasal 47 UU Perdagangan.

${ }^{2}$ Undang-Undang Nomor 8 Tahun 1999 Tentang Perlindungan Konsumen
Inkonsistensi antar peraturan perundangundangan sebagaimana disebutkan diatas jelas menjauhkan hukum dari cita utamanya yaitu hukum dibuat dan diberlakukan di masyarakat untukmenciptakan kesejahteraan bagimasyarakat dan tidak menimbulkan ketidakpastian hukum. Ironisnya, ketentuan dalam UUPK semakin tidak bisa mengakomodir upaya perlindungan hukum secara menyeluruh dikarenakan semakin pesat perkembangan perdagangan barang bekas yang dilakukan masyarakat tanpa mengindahkan syarat dan aturan yang berlaku yakni informasi bagi konsumen atas barang yang diperdagangkan.

Berbanding terbalik dengan ketentuan diatas, realita menunjukkan bahwa perkembangan dan persaingan dalam dunia usaha semakin ketat dan tidak sehat sehingga tidak sedikit pelaku usaha hanya mementingkan untuk mengejar dan meraup keuntungan sebesar-besarnya (profit oriented) tanpa memperhatikan mutu produk dan atau jasa yang mereka suguhkan. Kondisi tersebut tentu sangat merugikan konsumen secara finansial, terlebih dalam kesehatan.

Tujuan pemerintah melarang penjualan pakaian impor bekas tidak hanya untuk melindungi konsumen, tetapi juga bertujuan untuk meningkatkan iklim usaha yang kondusif dan jujur sejalan dengan perkembangan dunia usaha. Dari sudut pandang industri, impor pakaian bekas tentu akan sangat mengganggu pasar domestik yang merupakan pangsa pasar utama industri garmen kecil dan konveksi lokal dan nasional.

\section{Pakaian Impor Bekas}

Dilihat dari namanya, pakaian impor bekas jelas merupakan pakaian bekas pakai. Berbeda dengan pakaian reject yang merupakan pakaian baru namun terdapat cacat, seperti jahitan yang tidak rapi, salah kancing, dan salah potong, atau pakaian germent yang berasal dari sisa penjualan department store yang ditimbun selama bertahun-tahun di gudang kemudian dijual kembali oleh pihak-pihak tertentu. ${ }^{3}$ Ketiga macam pakaian ini memang

${ }^{3}$ http://www.kemendag.go.id/files/pdf/2015/07/14/ 
tidak seperti pakaian baru yang berkualitas dan dijual secara umum, namun harga ketiga pakaian tersebut jauh lebih murah.

Impor merupakan salah satu cara yang dilakukan untuk memenuhi kebutuhan dalam negeri. Kegiatan impor dilakukan hampir dalam segala sektor, baik itu sektor sandang, pangan maupun industri. Barang impor pun tidak selalu barang dalam keadaan baru, namun juga barang dalam keadaan bukan baru atau bekas, seperti mesin, pompa udara, peralatan industri dan pakaian bekas.

Negara asal pakaian bekas ini beragam, namun lebih banyak dari Jepang dan Korea sebab pakaian bekas yang berasal dari kedua negara tersebut memiliki kelebihan yaitu ukurannya hampir sama dengan ukuran orang Indonesia, selain style dan fashion merupakan faktor utama pemilihan pakaian yang akan dijual. Selain itu, budaya Jepang dan Korea juga sudah banyak masuk ke Indonesia, terlebih budaya fashion Jepang Harajuku dan Korea Hwalyu akhir-akhir ini cukup popular dan menjadi style di Indonesia. ${ }^{4}$

\section{Konsep Perlindungan Konsumen Pakaian Impor Bekas Menurut UUPK}

Istilah konsumen dalam konsep yuridis formal ditemukan pada Undang-Undang Nomor 8 Tahun 1999 Tentang Perlindungan Konsumen, yang menyatakan bahwa konsumen adalah setiap orang pemakai barang dan/atau jasa yang tersedia dalam masyarakat, baik bagi kepentingan diri sendiri, keluarga, orang lain maupun makhluk hidup lain dan tidak untuk diperdagangkan. Sedangkan perlindungan konsumen adalah segala upaya yang menjamin adanya kepastian hukum untuk memberi

publikasi-majalah-intra-edisi-v-2015-id0-1436856512. pdf. Diakses tanggal 1 September 2015 pukul 08.10 WIB.

${ }^{4}$ Louisa Wisnuwardhani dkk, Jurnal Ilmu Administrasi (JAB) Vol.1 Nomor 1 Tahun 2015 "Upaya Peningkatan Penjualan Baju BekasMelalui Media Facebook (Studi pada Viee Second Kalla)", Fakultas Ilmu Administrasi Universitas Brawijaya Malang. perlindungan kepada konsumen. ${ }^{5}$

Dalam rumusan pengertian ini "segala upaya menjamin kepastian hukum", merupakan benteng peniadaan kesewenang-wenangan yang merugikan pelaku usaha untuk melindungi kepentingan konsumen dalam suatu transaksi. Namun, bukan berarti kepentingan pelaku usaha tidak menjadi perhatian hukum, karena keberadaan perekonomian nasional banyak ditentukan oleh para pelaku usaha.

Munculnya UU Perlindungan Konsumen diharapkan dapat menempatkan posisi konsumen setingkat dengan pelaku usaha. Ada beberapa alasan mengapa konsumen harus dilindungi, antara lain; ${ }^{6}$ (a) Melindungi konsumen sama artinya dengan melindungi seluruh bangsa demi tujuan pembangunan nasional sebagaimana amanat Pembukaan UUD 1945; (b) Melindungi konsumen merupakan keharusan yang diperlukan untuk menghindari konsumen dari dampak negatif penggunaan teknologi; (c) Melindungi konsumenmerupakankeharusan yang diperlukan untuk mencipatakan iklim persaingan yang sehat secara jasmani dan rohani bagi para pelaku usaha guna menjaga kesinambungan pembangunannasional; (d)Melindungikonsumen merupakan keharusan yang diperlukan untuk menjamin dana pembangunan yang bersumber dari masyarakat.

Tujuan adanya peraturan terkait pelindungan untuk konsumen sebagai upaya untuk menjamin keseimbangan antara kepentingan konsumen, pelaku usaha dan pemerintah, sehingga tidak hanya konsumen yang dilindungi tetapi juga untuk kepentingan pelaku usaha. Tujuan tersebut antara lain adalah; ${ }^{7}$ (a) Menigkatkan kesadaran, kemampuan, dan kemandirian konsumenuntuk melindungi diri; (b) Mengangkat harkat dan martabat konsumen dengan cara menghindarkannya dari akses negatif pemakaian barang jasa; (c) Meningkatkan pemberdayaan

${ }^{5}$ Pasal 1 Nomor 1 Undang-Undang Perlindungan Konsumen.

'Shidarta, Hukum Perlindungan Konsumen Indonesia,(Jakarta:Grasindo, 2004), hal. 25.

${ }^{7}$ Pasal 3 Undang-Undang Nomor 8 Tahun 1999 Tentang Perlindungan Konsumen. 
konsumen dalam memilih, menentukan, dan menuntut hak-haknya sebagai konsumen; (d) Menciptakan sistem perlindungan konsumen yang mengandung unsur kepastian hukum dan keterbukaan informasi serta adanya akses untuk mendapatkan informasi; (e) Menumbuhkan kesadaran pelaku usaha mengenai pentingnya perlindungan konsumen sehingga tumbuh sikap yang jujur dan bertanggungjawab dalam berusaha; (f) Meningkatkan kualitas barang/jasa yang menjamin kelangsungan usaha produksi barang dan atau jasa, kesehatan, kenyamanan, keamanan, dan keselamatan.

Adapun materi yang mendapatkan perlindungan bukan sekedar fisik, namun juga hak-hak konsumen yang bersifat abstrak. Dengan kata lain, perlindungan konsumen sesungguhnya identik dengan perlindungan yang diberikan hukum terhadap hak-hak konsumen. Secara umum dikenal 4 (empat) hak dasar konsumen, yaitu: ${ }^{8}$ (a)Hak untuk mendapatkan keamanan dari barang dan jasa yang ditawarkan kepada konsumen (the right to safety). Produk barang dan jasa tidak boleh membahayakan jika dikonsumsi sehingga konsumen tidak dirugikan baik secara jasmani atau rohani. (b) Hak untuk mendapatkan informasi yang benar pada setiap produk yang diperkenalkan kepada konsumen (the right to be informed). Informasi tersebut diperlukan agar konsumen tidak mempunyai gambaran keliru atas produk barang dan jasa. Informasi tersebut dapat disampaikan dengan berbagai cara, baik melalui lisan, iklan, atau mencantumkan dalam kemasan produk. (c) Hak untuk memilih (the right to choose). Dalam mengkonsumsi suatu produk, konsumen berhak menentukan pilihannya. Konsumen tidak boleh mendapat tekanan dari pihak luar sehingga mereka bebas untuk membeli atau tidak membeli, dan seandainya konsumen jadi membeli, mereka juga bebas menentukan produk yang akan dibeli. (d) Hak untuk didengar (the right to be heard). Konsumen seringkali tidak puas mendapatkan informasi dari pedagang. Oleh

\footnotetext{
'Shidarta, Hukum Perlindungan Konsumen Indonesia,(Jakarta: Grasindo, 2004), hal. 20.
}

karena itu, konsumen berhak mengajukan permintaan informasi lebih lanjut terkait barang yang mereka beli.

\section{Konsep Perlindungan Konsumen Terhadap Pakaian Impor Bekas Menurut Undang-Undang Nomor 7 Tahun 2014 Tentang Perdagangan}

Perdagangan adalah aktivitas perekonomian yang berkaitan dengan transaksi barang dan/atau jasa, dilakukan oleh pelaku usaha dan bertujuan untuk mengalihkan hak atas barang dan/atau jasa kedua belah pihak untuk memperoleh imbalan maupun kompensasi. Oleh karena itu, praktek perdagangan merupakan urat nadi perekonomian nasional.

Perdagangan pakaian impor bekas adalah salah satu bentuk praktek perdagangan yang dilakukan oleh masyarakat. Perdagangan jenis ini terkait erat sekali dengan kegiatan impor, sehingga kebijakan dalam perdagangan impor menjadi salah satu alternatif dan sarat dengan praktek untuk melindungi dan mewujudkan perlindungan bagi konsumen sebagai pengguna dari produk impor tersebut.

Demi mewujudkan perlindungan maksimal kepada konsumen, salah satu program utama dalam pemberlakuan Undang-Undang Perdagangan adalah mewujudkan konsumen cerdas yakni konsumen yang kritis dan berani memperjuangkan hak dan kewajibannya serta mampu melindungi diri sendiri, keluarga, dan lingkungan dari barang dan jasa yang tidak sesuai dengan ketentuan, terlebih perlindungan atas kesehatan, keamanan, keselamatan dan lingkungan (K3L).

Dalam Undang-Undang Nomor 7 Tahun 2014 Tentang Perdagangan terdapat beberapa poin yang diatur terkait perdagangan yaitu: ${ }^{9}$ (a) Perdagangan dalam negeri; (b) Perdagangan luar negeri; (c) Perdagangan perbatasan; (d) Standardisasi; (e) Perdagangan melalui sistem elektronik; (f) Perlindungan dan pengamanan perdagangan; (g) Pemberdayaan koperasi serta usaha mikro, kecil, dan menengah; (h) Pengembanganekspor; (i) Kerjasama perdagangan

${ }^{9}$ Pasal 4 Undang-Undang Nomor 7 Tahun 2014 Tentang Perdagangan 
internasional; (j) Sistem informasi perdagangan; (k) Tugas dan wewenang pemerintah di bidang perdagangan; (l) Komite perdagangan nasional; (m) Komite perdagangan nasional; (n) Pengawasan; (o) Penyidikan.

Dalam point tentang perdagangan luar negeri, materinya terkait; (a) Ekspor; (b) Impor; (c) Perizinan ekspor dan impor; (d) Larangan dan pembatasan ekspor dan impor.

Pemerintah Pusat dan Pemerintah Daerah mempunyai peran dalam mengendalikan ketersediaan barang dan peredarannya di seluruh wilayah Negara Kesatuan Republik Indonesia dalam jumlah yang memadai, mutu yang baik, dan harga yang terjangkau. Pengaturan tentang impor dijelaskan pada Pasal 47 jelas dikatakan bahwa; (a.) Setiap importir wajib mengimpor barang dalam keadaan baru; (b.) Dalam hal tertentu Meteri dapat menetapkan Barang yang diimpor dalam keadaan tidak baru; (c.) Penetapan sebagaimana dimaksud pada ayat (2) disampaikan kepada Menteri yang menyelenggarakan urusan pemerintahan di bidang keuangan; (d.) Ketentuan lebih lanjut mengenai penetapan barang yang diimpor dalam keadaan tidak baru sebagaimana dimaksud pada ayat (2) diatur dengan Peraturan Menteri.

Melakukan impor barang keadaan tidak baru memang masih diperbolehkan dalam hal tertentu, namun yang dimaksud "dalam hal tertentu" adalah barang yang dibutuhkan oleh pelaku usaha berupa barang modal bukan baru yang belum dapat dipenuhi oleh sumber dari dalam negeri sehingga perlu diimpor dalam rangka proses produksi industri untuk tujuan pengembangan ekspor, peningkatan daya saing, efisiensi usaha, investasi, dan relokasi industri, pembangunan infrastruktur, dan/ atau diekspor kembali. Selain itu, dalam hal terjadi bencana alam dibutuhkan barang atau peralatan dalam kondisi tidak baru dalam rangka pemulihan dan pembangunan kembali sebagai akibat bencana alam serta barang bukan baru untuk keperluan lainnya sesuai dengan peraturan perundang-undangan. Oleh karena itu, pemerintah memperbolehkan melakukan impor barang tidak baru hanya pada kondisi- kondisi tertentu.

Terkait dengan pakaian impor bekas memang tidak secara tersurat dijelaskan dalam undangundang ini, namun dapat diketahui dari Peraturan Menteri Perdagangan Nomor 51/M-DAG/ PER/7/2015 Tentang Larangan Impor Pakaian Bekas yang disebutkan dalam Pasal 2 dan 3 bahwa, "pakaian bekas dilarang untuk diimpor ke dalam wilayah Negara Kesatuan Republik Indonesia", dan "pakaian bekas yang tiba di wilayah Negara Kesatuan Republik Indonesia pada atau setelah tanggal Peraturan Menteri ini berlaku wajib dimusnahkan sesuai ketentuan peraturan perundang-undangan".

Setiap produsen atau importir yang memperdagangkan pakaian impor bekas diwajibkan selalu memikirkan aspek keamanan, keselamatan, kesehatan, serta lingkungan hidup sebelum melakukan transaksi impor. Selain itu, produsen atau importir diharuskan mendaftarkan barang yang diperdagangkan kepada pihak Kementerian Perindustrian dan Perdagangan sehingga pemerintah dapat mengontrol dan mengetahui kondisi barang tersebut dan barang tersebut termasuk barang legal atau illegal sebelum diedarkan kepada masyarakat. Tindakan tersebut harus dilakukan dan wajib dilakukan berdasarkan Pasal7 huruf d Undang-Undang Perlindungan Konsumen yang berbunyi "menjamin mutu barang dan/atau jasa yang diproduksi dan/atau diperdagangkan berdasarkan ketentuan standar mutu barang dan/ atau jasa yang berlaku".

Barang ataupun jasa yang beredar juga harus memiliki standardisasi yang telah memenuhi ketentuan standar mutu barang dan/atau jasa yang berlaku dan digolongkan sebagai barang yang memiliki standar nasional Indonesia (SNI) oleh pemerintah yang bertanggung jawab atas urusan tersebut. ${ }^{10}$ PemberlakukanSNI

\footnotetext{
${ }^{10}$ Standardisasi merupakan proses merumuskan, menetapkan, menerapkan, memelihara, memberlakukan, dan mengawasi standar yang dilakukan secara tertib dan bekerjasama dengan semua pihak. Yangmana diberlakukan persyaratan teknis atau sesuatu yang dibakukan, termasuk tata cara dan metode yang disusun berdasarkan konsesus semua pihak/ pemerintah/ keputusan internasional yang terkait dengan memperhatikan syarat
} 
dilakukan dengan mempertimbangan aspek; ${ }^{11}$ (a.) Keamanan, keselamatan, kesehatan dan lingkungan hidup; (b.) Daya saing produsen nasional dan persaingan usaha; (c.) Kemampuan dan kesiapan dunia usaha nasional; (d.) Kesiapan infrastruktur lembaga penilaian kesesuaian; (e.) Budaya, adat istiadat atau tradisi berdasarkan kearifan lokal.

\section{Metode Penelitian}

\section{Jenis Penelitian}

Jenis penelitian ini termasuk dalam kategori penelitian hukum dengan pendekatan sosiologis-empiris. Dalam tulisan ini, penulis mendeskripsikan kendala pencegahan perdagangan pakaian impor bekas secara mendalam sebagai suatu keadaan atau fenomena sosial dari objek penelitian yang diteliti dengan cara mengembangkan konsep yang ada serta menghimpun kenyataan yang terjadi.

Termasuk di dalam penelitian ini adalah identifikasi proses pemunculan hukum yang dalam pandangan Soetandyo Wignjosoebroto, disebut sebagai penelitian non-doktrinal atau socio legal research, karena merupakan studistudi empiris untuk menemukan teori-teori mengenai proses terjadinya dan bekerjanya hukum di masyarakat, yaitu menganalisis aspek-aspek hukum perlindungan konsumen dan perdagangan terhadap perdagangan pakaian impor bekas yang semakin besar. ${ }^{12}$ Selanjutnya,

keselamatan, keamanan, kesehatan, lingkungan hidup, perkembangan ilmu pengetahuan dan teknologi, pengalaman, serta perkembangan pada masa kini dan masa depan untuk memperoleh manfaat sebesarbesarnya. Standardisasi ini kemudian disebut SNI yang ditetapkan oleh lembaga yang menyelenggarakan pengembangan dan pembinaan di bidang standardisasi (Ketentuan Umum UU Perdagangan).

${ }^{11}$ Pasal 60 Undang-Undang Nomor 7 Tahun 2014 Tentang Perdagangan.

${ }^{12}$ Menurut Soetandyo Wignjosoebroto, penelitian hukum sosiologis adalah penelitian yang berupa studi empiris untuk menemukan teori-teori tentang proses terjadinya dan bekerjanya hukum dalam masyarakat. Penelitian ini, meminjam istilah Soerjono Soekanto, dikategorikan sebagai penelitian hukum empiris, tepatnya penelitian terhadap identifikasi hukum, penelitian identifikasi hukum adalah penelitian identifikasi proses pemunculan hukum yang, dalam pandangan Soetandyo Wignjosoebroto, disebut sebagai penelitian non-doktrinal atau socio legal research, karena peneliti melakukan pengkajian terhadap aspekaspek dan peraturan perundang-undangan yang berlaku untuk mengetahui upaya hukum yang dilakukan untuk meminimalisir, mencegah, dan memutus mata rantai perdagangan pakaian impor bekas.

\section{Lokasi Penelitian}

Penelitian ini dilakukan di Kantor Dinas Perindustrian dan Perdagangan Kota Malang terkait upaya perlindungan hukum terhadap pedagang pakaian impor bekas. Selain itu, penelitian dilakukan di pusat perdagangan pakaian impor bekas sebagai salah satu bukti bahwa keberadaan perdagangan pakaian impor bekas tersebut masih aktif dan memiliki banyak peminat, seperti di pasar Comboran, Kasin dan Kawasan Joyo Kelurahan Merjosari.

\section{Jenis dan Sumber Data}

Soerjono Soekanto dan Sri Mamudji menyatakan bahwa data dalam penelitian hukum terdapat tiga macam yaitu data primer, data sekunder dan data tersier. ${ }^{13}$ (a) Data Primer (primary data) adalah data yang diperoleh secara langsung dari sumber utama. Dalam konteks penelitian ini, data primer diperoleh dari keterangan Ketua Dinas Perindustrian dan Perdagangan Kota Malang dan para pedagang pakaian bekas. (b) Data Sekunder adalah data-data yang diperoleh dari sumber kedua yang merupakan pelengkap berupa data-data kepustakaan dan bahan kepustakaan yang relevan dengan tema yang diangkat. (c) Data Tersier adalah data-data penunjang, yakni bahan-bahan yang memberi petunjuk dan penjelasan terhadap data primer dan data sekunder, di antaranya kamus hukum dan ensiklopedi.

merupakan studi-studi empiris untuk menemukan teori-teori mengenai proses terjadinya dan mengenai proses bekerjanya hukum di dalam masyarakat Lihat. Bambang Sunggono, Metode Penelitian Hukum, (Jakarta: PT. Raja Grafindo Persada, 2003), hal. 42; Soerjono Soekanto, Pengantar Penelitian Hukum, (Jakarta: UI Press, 2000), hal. 50.

${ }^{13}$ Soerjono Soekanto dan Sri Mamudji, Penelitian Hukum Normatif: Suatu Tinjauan Singkat, (Jakarta: PT. Raja Grafindo Persada, 2003), hal. 12-13. 


\section{Teknik Pengumpulan Data}

Terdapat tiga teknik pengumpulan data yang digunakan dalam penelitian ini yaitu; (1) wawancara (depth interview dan structured interview); (2) pengamatan tidak terlibat (non-participant observation); dan (3) Metode dokumentasi. ${ }^{14}$

\section{Analisis Data}

Metode analisis data yang digunakan dalam penelitian ini adalah metode yuridis kualitatif, dengan tujuan memperoleh data deskriptif reflektif yaitu mengabstraksikan seluruh data yang diperoleh baik melalui interview, maupun dokumentasi untuk diidentifikasikan ke dalam pengelompokan data secara deskriptif, kualitatif dan bukan angka-angka.

Penelitian hukum ini mengkaji hukum yang dikonsepkan sebagai norma atau kaidah yang berlaku dalam masyarakat, dan menjadi acuan perilaku setiap orang. Dengan jenis penelitian ini dilakukan kajian terhadap taraf sinkronasi yaitu sampai sejauh mana hukum positif yang ada sinkron atau serasi satu sama lain,15 serta kajian komprehensif analitis terhadap bahan hukum primer dan bahan hukum sekunder. Hasil kajian dipaparkan secara lengkap, rinci, jelas dan sistematis sebagai karya ilmiah.

\section{Hasil Penelitian dan Pembahasan}

Kendala Dinas Perindustrian dan Perdagangan Kota Malang Dalam Menangani Pencegahan Pakaian Impor Bekas

Pemerintah mulai perlahan namun pasti melakukan pembenahan pakaian impor bekas. Kementerian Perdagangan hadir menyelesaikan persoalan masyarakat dengan menunjukkan bahwa pakaian impor bekas penuh dengan bakteri dan tak layak pakai. Upaya Kementerian Perdagangan ini merupakan satu tindakan penting untuk melindungi masyarakat dari barang yang mengancam kesehatan. Meskipun bukan hal baru terkait pelarangan memperdagangkan pakaian impor

\footnotetext{
${ }^{14}$ Burhan Ash-shofa, Metode Penelitian Hukum, (Jakarta: Rineka Cipta, 1998), hal. 61.

${ }^{15}$ Bambang Sunggono, Metode Penelitian, hal. 97.
}

bekas, namun Kementerian Perdagangan ingin hadir di tengah masyarakat untuk menjawab persoalan masyarakat dan untuk menciptakan harmonisasi perdagangan. ${ }^{16}$

Hal tersebut diatas selaras dengan pendapat Lawrence M. Friedman yang menyatakan bahwa efektifitas hukum memiliki hubungan yang sangat erat dengan persoalan penerapan, pelaksanaan dan penegakan hukum yang didasari oleh unsur subtansi hukum, struktur hukum dan budaya hukum, demi tercapainya tujuan hukum, sehingga hukum benar-benar berlaku secara filosofis, yuridis dan sosiologis. ${ }^{17}$

Oleh karenanya, terdapat beberapa kendala dalam penanganan perdagangan pakaian impor bekas di Kota Malang yaitu: (1) Upaya dilakukan hanya dalam taraf sosialisasi terhadap para pedagang pakaian impor bekas tanpa adanya tindak lanjut. Upaya pencegahan Disperindag Kota Malang terhadap perdagangan pakaian impor bekas baru sebatas sosialisasi dalam bentuk pendataan dan himbauan, belum melewati tahap penyitaan dan pemberian sanksi. Menurut Soerjono Soekanto, sosialisasi merupakan suatu mekanisme dalam proses pengendalian sosial. Oleh karena itu, sosialisasi tersebut perlu dilakukan untuk menunjang fungsi hukum sebagai social control sehingga hukum dapat mengendalikan pola tingkah laku manusia. Selain itu, kesadaran masyarakat atas

${ }^{16}$ Pada saat Menteri Perdagangan, Rachmat Gobel, periode 2014-2015 sangat gencar melakukan perlawanan pada para penyelundup pakaian impor bekas. Alasan dibalik perlawanan ini disebabkan adanya uji sampel yang pernah dilakukan pada pakaian-pakaian bekas yang dijual di Pasar Senin, Jakarta. Berdasarkan hasil uji sempel ditemukan adanya beberapa jenis mikroorganisme yakni bakteri staphylococcus aures, bakteri escherichia coli (e-coli), dan jamur kupang. Bakteri e-coli jika masuk ke dalam tubuh manusia dapat menyebabkan gangguan pencernaan seperti diare. Sedangkan bakteri aureus bisa menyebabkan bisul, panu, jerawat, sampai infeksi pada luka. Dan yang lebih seram adalah jamur jenis Kapang dan Khamir. Mereka dapat menyebabkan gatal-gatal, alergi, dan infeksi saluran kelamin. Lihat. http://finance.detik.com/read/2015/03/15/143713/2859 115/4/mulai-2016-perdagangan-pakaian-bekas-impordilarang. Diakses tanggal 1 September 2015 pukul 07.30 WIB.

${ }^{17}$ Soerjono Soekanto, Faktor-Faktor Yang
Mempengaruhi Penegakan Hukum,(Jakarta: Rajawali, 1983), hal. 34. 
hukum perlu ditumbuhkan sehingga masyarakat mengetahui betapa pentingnya suatu aturan hukum. Kesadaran tersebut dapat ditumbuhkan salah satunya melalui sosialisasi sehingga mereka mengetahui tentang aturan yang harus ditaati dan adanya sanksi jika aturan tersebut tidak dipatuhi.18 Sosialisasi dapat dipahami sebagai suatu proses dimana seseorang dapat menghayati serta memahami norma-norma dalam masyarakat tempat tinggalnya sehingga mereka membentuk kepribadiannya sesuai dengan nilai-nilai yang terkandung dalam norma-norma tersebut. Namun disisi yang lain, sosialisasi tanpa adanya penindakan lebih lanjut, dapat menjadikan para pedagang tetap konsisten pada mata pencariannya dengan menjual pakaian bekas. Padahal pakaian bekas merupakan barang ilegal, sehingga perlu melakukan tindakan penerapan sanksi. Dalam penegakan hukum, Kementerian Perdagangan telah bekerjasama dengan Bareskrim Polri tentang peningkatan penegakan hukum di bidang perlindungan konsumen dan metrologi legal. Kerjasama tersebut memberi peluang kepada Desperindag Kota Malang untuk melakukan berkoordinasi dengan mengerahkan Satua Polisi Pamong Praja (Satpol PP) dan penindakan lebih lanjut sedangkan terkait sanksi diserahakan pada pihak Kepolisian.

Struktur hukum (legal structure) terdiri dari lembaga hukum yang ada dimaksudkan untuk menjalankan seperangkat hukum yang ada. Struktur merupakan pola yang menunjukkan tentang bagaimana hukum dijalankan menurut ketentuan-ketentuan formalnya. Struktur juga menunjukkan bagaimana pengadilan, pembuat hukum dan badan penegak hukum serta proses hukum itu berjalan dan dijalankan. Pelarangan perdagangan pakaian impor bekastetap bersama-, dirasakan kurang adanya perhatian dari para penegak hukum, terbukti belum ada tindakan lanjut secara pasti terhadap sanksi yang akan diberikan bagi para pedagang pakaian, sehingga para pedagang semakin marak dan nyaman untuk tetap pada bisnis tersebut. Sedangkan

\footnotetext{
${ }^{18}$ Soerjono Soekanto, Sosiologi Suatu Pengantar, (Jakarta: PT. RajaGrafindo Persada, 1982), hal. 54.
}

tujuan adanya sanksi ini sebagai salah satu alat pengontrol perilaku masyarakat dengan bersifat menakuti-nakuti, memperbaiki dan membinasakan..$^{19}$ (2) Peraturan-peraturan yang telah dikeluarkan oleh pemerintah pusat sebagai upaya pencegahan terhadap perdagangan pakaian impor bekas masih belum terealisasi dalam bentuk Peraturan Daerah. Regulasi terkait impor pakaian bekas bukan merupakan kebijakan baru dari pemerintah. Larangan impor pakaian bekas sudah dikeluarkan pemerintah sejak tahun 1982 dan masih tetap berlaku, melalui SK Menteri Perdagangan dan Koperasi Nomor 28 Tahun 1982 Tentang Ketentuan Umum di Bidang Impor Pasal 3 yang menyatakan bahwa, "Barang-barang yang diimpor harus dalam keadaan baru". Kemudian muncul Keputusan Menteri Perindustrian dan Perdagangan Republik Indonesia Nomor 230/MPP/Kep/7/1997 Tentang Barang Yang Diatur Tata Niaga Impornya disebutkan dalam Lampiran I Nomor 108, bahwa gombal baru dan bekas (termasuk pakaian impor bekas) merupakan limbah yang diatur dalam pengimporannya. Pada saat itu, gombal baru dan bekas ini masih mencakup kain perca yang digunakan sebagai bahan baku untuk proses produksi dan terlarang untuk diperjual-belikan. Impor hanya boleh dilakukan oleh Importir Produsen (IP) yang ditetapkan oleh Departement Perindustrian dan Perdagangan, ehingga impor dapat dilakukan setelah mendapat legalitas impor dari Deperdag. Keputusan Menteri Perindustrian dan Perdagangan RI tersebut direvisi pada tahun 2002. Dalam Keputusan Menteri Perindustrian dan Perdagangan RI Nomor 642/MPP/Kep/9/2002 Tentang Perubahan Lampiran I Barang Yang Diatur Tata Niaga Impornya, dikatakan bahwa mengimpor gombal baru dan bekas dilarang, sebab kebutuhan atas kain perca sudah dapat dipenuhi dari produksi dalam negeri. Peraturan tersebut tentu tidak hanya untuk kain perca, namun juga pada pakaian bekas yang sengaja diimpor untuk diperdagangkan. Jika akhir-akhir ini sering

${ }^{19}$ Soufnir Chibro, Pengaruh Tindak Pidana Penyelundupan Terhadap Pembangunan, (Jakarta: Sinar Grafika, 1992), hal. 28. 
terjadi penangkapan terhadap pelaku impor pakaian bekas dan disertai penyitaannya, haltersebut semata-mata karena pemerintah ingin menegakkan hukum kepada setiap pelanggar. Sebagai gambaran, tidak ada satu negara pun di dunia ini, termasuk negara-negara Asean yang mengijinkan impor pakaian bekas masuk ke negaranya. Hal tersebut juga berlaku di Indonesia sebagai upaya pemerintah untuk melindungi konsumen, pasar dan produksi dalam negeri. ${ }^{20}$ Karena semakin bertambahnya jumlah penjual pakaian impor bekas dan tidak memperdulikan larangan dan peraturan yang ada, maka dibuatlah Peraturan Menteri Perdagangan Tahun 2009 tentang Ketentuan Umum Bidang Impor, yang disebutkan dalam Pasal 6 : (a) Barang yang diimpor harus dalam keadaan baru; (b) Dan dalam hal tertentu, Menteri dapat menetapkan barang yang diimpor dalam keadaan bukan baru berdasarkan Peraturan Perundang-undangan, Kewenangan Menteri, dan atau pertimbangan teknis dari instansi pemerintah lainnya.

Pasal 7 juga menyebutkan bahwa "terhadap impor barang tertentu yang dapat ditetapkan pengaturan impor tersendiri, kecuali barang yang secara tegas dilarang untuk diimpor berdasarkan ketentuan peraturan perundangundangan".

Laranganimpor barang bekas dalam Peraturan Menteri Perdagangan tahun 2009 kemudian diadopsi ke dalam peraturan yang lebih tinggi, yakni Undang-Undang Perdagangan terbaru tahun 2014.21 Keluarnya undang-undang tersebut diartikan sebagai upaya dalam meningkatkan pertumbuhan ekonomi nasional serta berdasarkan asas kepentingan nasional, kepastian hukum, dan keadilan.

Dikeluarkannya Peraturan Menteri Perdagangan RI Nomor 51/M-DAG/PER/7/2015 Tentang Larangan Impor Pakaian Bekas yang

${ }^{20} \mathrm{http}: / / \mathrm{www}$. kemenperin.go.id/artikel/579/ Penjelasan-Dirjen-Perdagangan-Luar-Negeri-KepadaWartawan-Tentang-Larangan-Impor-Pakaian-Bekas diakses 10 September 2015 pukul 15.30 WIB

${ }^{21}$ Pasal 47 Undang-Undang Nomor 7 Tahun 2014 Tentang Perdagangan. tertuang dalam Pasal2, "pakaian bekas dilarang untuk diimpor ke dalam wilayah Negara Kesatuan Republik Indonesia". Peraturan menteri ini secara tegas melarang, berbeda dengan peraturan perundang-undangan sebelumnya, yang mana pelarangannya masih bersifat global, tanpa ada penyebutan kata "pakaian bekas impor".

Thomas Trikasih Lembong selaku Menteri Perdagangan sedang menyiapkan Rancangan Peraturan Presiden (Perpres) tentang pakaian bekas impor yang nantinya akan menjadi landasan dalam daftar barang terlarang untuk diperdagangkan di dalam negeri. Peraturan Presiden (Perpres) tersebut akan menjadi penegas Undang-Undang Perdagangan Tahun 2014. Berlakunya peraturan baru tersebut yang ditargetkan akan selesai pada tahun ini, diharapkan akan menjadi acuan formil sehingga kegiatan kegiatan perdagangan pakaian bekas impor dalam wilayah seluruh Indonesia tidak ada lagi. Direktur Impor Direktorat Jenderal Perdagangan Luar Negeri Kementerian Perdagangan Thamrin Latuconsina mengatakan bahwa pelarangan impor pakaian bekas sudah ada, namun dalam penanganan terdapat kelemahan. Kita sedang mempersiapkan Perpres yang akan mengatur tiga hal, Perpres tersebut nantinya akan diatur lebih menyeluruh terkait pelarangan impor, pembatasan, dan juga pengawasan terhadap pakaian bekas yang sudah beredar".22

Direktur Jenderal Standardisasi dan Perlindungan Konsumen (Dirjen SPK) Kementerian Perdagangan (Kemendag), Widodo mengatakan bahwa setelah aturan tersebut diberlakukan, diharapkan barangbarang impor haruslah barang-barang baru kecuali barang modal seperti mesin dan alat berat. Barang modal bukan baru yang diimpor harus dengan persetujuan berbagai pihak seperti Kemendag dan Kementerian Perindustrian

${ }^{22}$ http://www.kemendag.go.id/files/pdf/2015/07/14/ publikasi-majalah-intra-edisi-v-2015-id0-1436856512. pdf. Diakses tanggal 1 September 2015 pukul 08.10 WIB. 
(Kemenperin). ${ }^{23}$

Rentan tahun 1982-2015 telah banyak peraturan perundang-undangan yang dijadikan referensi terkait larangan pakaian impor bekas. Peraturan tersebut menekankan terhadap perlindungan terhadap para konsumen. Dengan pertimbangan terhadap perlindungan keamanan, keselamatan dan kesehatan yang berkaitan dengan kehidupan manusia. Selain itu, juga terkait perlindungan kepentingan pembangunan ekonomi nasional, penciptaan kondisi perdagangan dan pasar dalam negeri yang sehat, serta iklim usaha yang kondusif.

Ir. Agus Pratoyo, MT24 selaku Kepala Bidang Perlindungan Konsumen Disperindag Kota Malang mengatakan bahwa upaya yang harus dilakukan Disperindag Kota Malang terkait kebijakan larangan penjualan pakaian impor bekas yaitu dengan melakukan sosialisasi-sosialisasi intens kepada masyarakat dan menindak tegas pelaku penjual pakaian impor bekas. Meskipun belum ada surat edaran resmi dari pemerintah pusat, instruksi lisan oleh pemerintah pusat melalui himbauan dan siaran media-media massa nasional akan ditindaklanjuti. Menurutnya, keputusan pemerintah pusat tersebut terkait erat dengan sumber hidup orang banyak, terutama para pedagang pakaian bekas, oleh karenanya pemerintah akan mengambil langkah bijaksana agar tidak menimbulkan dampak buruk terhadap kehidupan para pedagang. "Jadi ada dua solusi yang mau kita tawarkan kepada pedagang; Pertama, batasi pasokan pakaian bekas dan habiskan stok yang ada. Kedua, kita akan tegaskan supaya sebelum dijual, semua pakaian harus dilaundry sehingga harga jual ikut naik. Memang kami harus hati-hati dalam menindaklanjuti keputusan menteri perdagangan ini, kerana berdagang pakaian bekas adalah sumber hidup pedagang."

${ }^{23}$ http://finance.detik.com/read/2015/03/15/143713 2859115/4/mulai-2016-perdagangan-pakaian-bekasimpor-dilarang. Diakses tanggal 1 September 2015 pukul 07.30 WIB.

${ }^{24} \mathrm{http}: / / \mathrm{ww}$ w.radarmalang.com/2015/03/ pedagang-pakaian-bekas-protes-kebijakan-menteriperdagangan/. Diakses tanggal 10 Oktober 2015 pukul 10.00 WIB
Tentang rencana penertiban pedagang pakain bekas, Pemerintah Kota sementara ini belum merencanakan penertiban, karena masih ada agenda penting lain yang harus diselesaikan. (3) Perdagangan Pakaian Impor Bekas Menjadi Salah Satu Sumber Utama Mata Pencaharian Pedagang

Sulitnya lapangan pekerjaan menjadi motivasi tersendiri bagi para pedagang untuk melakukan perdagangan pakaian impor bekas dengan mudah. Demikian juga bagi para pecinta pakaian impor bekas, penjualan pakaian impor bekas terbilang mudah dan dapat dijangkau semua kalangan. Barang yang didapat diimpor melaui pelabuhan-pelabuhan kecil di beberapa pulau yang kategori illegal. Sudah menjadi keumuman, suatu peraturan yang tidak sesuai dengan norma di masyarakat akan mendapat penolakan. Tidak sedikit para pedagang pakaian bekas di Kota Malang menolak adanya larangan ini. Para pedagang menganggap kebijakan pemerintah tidak masuk akal dan terlalu mengada-ngada. Menurut pedagang babebo, sulitnya ketersediaan lapangan kerja serta PHK besar-besaran di sejumlah perusahaan akibat perlambatan ekonomi mengakibatkan banyak terjadi pengangguran di Indonesia. Jika perdagangan pakaian impor bekas dihentikan, maka akan menambah tingkat pengangguran masyarakat. Selain itu, sanksi yang diterapkan hanya bisa menyentuh para importir.

Sejalan dengan teori efektifitas hukum, Friedman mengatakan bahwa budaya hukum adalah kebiasaan-kebiasaan, opini-opini, metode berpikir dan bertindak, baik dari para penegak hukum maupun dari warga masyarakat. Budaya hukum merupakan sikap manusia terhadap hukum dan sistem hukum. Sebaik apapun penataan struktur hukum untuk menjalankan aturan hukum yang ditetapkan dan sebaik apapun kualitas substansi hukum yang dibuat tanpa didukung budaya hukum oleh orang-orang yang terlibat dalam sistem sosial masyarakat, maka penegakan hukum tidak akan berjalan secara efektif. Oleh karenanya, Lawrence M Friedman menekankan pentingnya budaya hukum (legal culture). 
Hukum memiliki fungsi sebagai sarana social control yaitu upaya untuk mewujudkan kondisi seimbang dalam masyarakat, yang bertujuan untuk menciptakan suatu keadaan serasi antara stabilitas dan perubahan di masyarakat social engineering. Selain itu, hukum juga memiliki fungsi sebagai sarana pembaharuan dalam masyarakat. Hukum dapat berperan dalam mengubah pola pemikiran masyarakat dari pola pemikiran tradisional ke dalam pola pemikiran rasional atau modern.

Efektifitas hukum adalah pengaruh hukum terhadap masyarakat, inti dari pengaruh hukum

\section{DAFTAR PUSTAKA}

Sunggono, Bambang. 2003. Metode Penelitian Hukum. Jakarta:PT. Raja Grafindo Persada.

Soekanto, Soerjono. 1983. Faktor-Faktor Yang Mempengaruhi Penegakan Hukum. Jakarta: Rajawali, 1983.

Soejono dan Abdurrahman. 1997. Metode Penelitian: Suatu Pemikiran dan Penerapan. Jakarta:PT. Rineka Cipta.

Soekanto. Soerjono. 2000. Pengantar Penelitian Hukum. Jakarta: UI Press.

Soekanto, Soerjono dan Sri Mamudji. 2003. Penelitian Hukum Normatif: Suatu Tinjauan Singkat.Jakarta: PT. Raja Grafindo Persada.

Shidarta. 2004. Hukum Perlindungan Konsumen Indonesia. Jakarta:Grasindo.

Louisa Wisnuwardhani dkk, Jurnal Ilmu Administrasi (JAB) Vol.1 Nomor 1 Tahun 2015 “Upaya Peningkatan Penjualan Baju BekasMelalui Media Facebook (Studi pada Viee terhadap masyarakat adalah prilaku warga masyarakat yang sesuai dengan hukum yang berlaku. Kalau masyarakat berprilaku sesuai dengan yang diharapkan atau yang dikendaki oleh hukum, maka dapat dikatakan bahwa hukum tersebut efektif.

Second Kalla)", Fakultas Ilmu Administrasi Universitas Brawijaya Malang.

http://www.kemendag.go.id/id/publikasiperdagangan/publikasi-intra-edisi-ketiga. Diakses tanggal 13 Oktober 2015 pukul 11.30 WIB.

http://www.kemendag.go.id/files/pdf/2015/07/14/ publikasi-majalah-intra-edisi-v-2015id0-1436856512.pdf. Diakses tanggal 1 September 2015 pukul 08.10 WIB.http:// www.kemenperin.go.id/artikel/579/ Penjelasan-Dirjen-Perdagangan-LuarNegeri-Kepada-Wartawan-TentangLarangan-Impor-Pakaian-Bekas diakses 10 September 2015 pukul 15

http://www.radarmalang.com/2015/03/pedagangpakaian-bekas-protes-kebijakan-menteriperdagangan/. Diakses tanggal 10 Oktober 2015 pukul 10.00 WIB. 